\title{
Aged garlic extract and its constituent, S-allyl-L-cysteine, induce the apoptosis of neuroblastoma cancer cells due to mitochondrial membrane depolarization
}

\author{
YUTA KANAMORI $^{1}$, LISA DALLA VIA ${ }^{2}$, ALBERTO MACONE $^{1}$, GIANLUCA CANETTIERI $^{3,4}$, \\ ANTONIO GRECO $^{5}$, ANTONIO TONINELLO ${ }^{4,6}$ and ENZO AGOSTINELLI ${ }^{1,4}$ \\ ${ }^{1}$ Department of Biochemical Sciences ‘A. Rossi Fanelli', Sapienza University of Rome, I-00185 Rome; \\ ${ }^{2}$ Department of Pharmaceutical and Pharmacological Sciences, University of Padua, I-35131 Padua; \\ ${ }^{3}$ Pasteur Laboratory, Department of Molecular Medicine, Sapienza University of Rome, I-00161 Rome; \\ ${ }^{4}$ International Polyamines Foundation-ONLUS, I-00159 Rome; ${ }^{5}$ Department of Sensory Organs, Sapienza University of Rome, \\ I-00161 Rome; ${ }^{6}$ Department of Biomedical Sciences, University of Padua, I-35131 Padua, Italy
}

Received August 7, 2019; Accepted September 19, 2019

DOI: $10.3892 /$ etm.2019.8383

\begin{abstract}
Aged garlic extract (AGE) has been demonstrated to have therapeutic properties in tumors; however its mechanisms of action have not yet been fully elucidated. A previous study revealed that AGE exerts an anti-proliferative effect on a panel of both sensitive [wild-type (WT)] and multidrug-resistant (MDR) human cancer cells. Following treatment of the cells with AGE, cytofluorimetric analysis revealed the occurrence of dose-dependent mitochondrial membrane depolarization
\end{abstract}

Correspondence to: Professor Enzo Agostinelli, Department of Biochemical Sciences 'A. Rossi Fanelli', Sapienza University of Rome, Piazzale Aldo Moro 5, I-00185 Rome, Italy

E-mail: enzo.agostinelli@uniroma1.it

Abbreviations: AGE, aged garlic extract; SAC, S-allyl-L-cysteine; SAMC, S-allylmercaptocysteine; ROS, reactive oxygen species; RNS, reactive nitrogen species; CNS, central nervous system; WT, wild-type; MDR, multidrug-resistant; NB, neuroblastoma; RLM, rat liver mitochondria; MTT, thiazolyl blue tetrazolium bromide; FBS, fetal bovine serum; JC-1, 5,5',6,6'-tetrachloro-1,1',3,3'-tetraethylimidacarbocyanine iodide; BSA, bovine serum albumin; $\Delta \psi \mathrm{m}$, mitochondrial membrane potential; $\mathrm{TPP}^{+}$, tetraphenylphosphonium; $\Delta \mu \mathrm{H}^{+}$, electrochemical gradient; $\Delta \mathrm{pH}_{\mathrm{m}}$, mitochondrial electrochemical gradient; MMD, mitochondrial membrane depolarization; MPT, mitochondrial permeability transition; CsA, cyclosporin A; NADH, nicotinamide adenine dinucleotide reduced form; NADPH, nicotinamide adenine dinucleotide phosphate reduced form; DMO, 5,5'-dimethyl-oxazolidine-2,4-dione; OPA, o-phthalaldehyde; GC-MS, gas chromatography-mass spectrometry; TBDMS, tert-butyldimethylsilyl;MTBSTFA, $N$-tert-butyldimethylsilyl- $N$-methyltrifluoroacetamide; TIC, total ion current; SIM, single ion monitoring

Key words: aged garlic extract, S-allyl-L-cysteine, anti-proliferative activity, human neuroblastoma cancer cells, mitochondria, mitochondrial membrane depolarization
(MMD). In this study, in order to further clarify the mechanisms of action of AGE, the effects of AGE on mitochondria isolated from rat liver mitochondria (RLM) were also examined. AGE induced an effect on the components of the electrochemical gradient $\left(\Delta \mu_{\mathrm{H}}^{+}\right)$, mitochondrial membrane potential $\left(\Delta \Psi_{\mathrm{m}}\right)$ and mitochondrial electrochemical gradient $\left(\Delta \mathrm{pH}_{\mathrm{m}}\right)$. The mitochondrial membrane dysfunctions of RLM induced by AGE, namely the decrease in both membrane potential and chemical gradient were associated with a higher oxidation of both the endogenous glutathione and pyridine nucleotide content. To confirm the anti-proliferative effects of AGE, experiments were performed on the human neuroblastoma (NB) cancer cells, SJ-N-KP and the MYCN-amplified IMR5 cells, using its derivative S-allyl-L-cysteine (SAC), with the aim of providing evidence of the anticancer activity of this compound and its possible molecular mechanism as regards the induction of cytotoxicity. Following treatment of the cells with SAC at $20 \mathrm{mM}$, cell viability was determined by MTT assay and apoptosis was detected by flow cytometry, using Annexin V-FITC labeling. The percentages of cells undergoing apoptosis was found to be $48.0 \%$ in the SJ-N-KP and 50.1\% in the IMR5 cells. By cytofluorimetric analysis, it was suggested that the target of SAC are the mitochondria. Mitochondrial activity was examined by labeling the cells with the probe, 5,5',6,6'-tetrachloro-1,1',3,3'-tetraethylimidacarbocyanine iodide (JC-1). Following treatment with $\mathrm{SAC}$ at $50 \mathrm{mM}$, both NB cell lines exhibited a marked increase in MMD. On the whole, the findings of this study indicate that both natural products, AGE and SAC, cause cytotoxicity to tumor cells via the induction of mitochondrial permeability transition (MPT).

\section{Introduction}

Garlic (Allium sativum L.) is a species of the onion family, and has been widely used as a food and also as a folk medicine. A previous study demonstrated that aged garlic extract (AGE) exerts an anti-proliferative effect on a panel of both sensitive [wild-type (WT)] and multidrug-resistant (MDR) 
human cancer cells (1). Following treatment of the cells with AGE, cytofluorimetric analysis revealed the occurrence of dose-dependent mitochondrial membrane depolarization (MMD) (1). A large number of epidemiological investigations have suggested that garlic is active in the prevention and treatment of various diseases with multiple pharmacological functions, such as anticarcinogenic (2), antithrombotic (3), hypolipidemic (4) and hepatoprotective (5) activities. It has been reported that garlic is able to suppress carcinogenesis and to inhibit the proliferation of cancer cells (e.g., esophageal, gastric, colorectal, lung, skin and prostate cancer cells) in vivo and in vitro (6). These studies have yielded significant findings, since the number of cancer patients worldwide has recently increased (1). Moreover, garlic has been reported to be beneficial in preventing neurodegeneration due to its antioxidant and amyloid $\beta(\mathrm{A} \beta)$-lowering properties (7). Among a number of different natural products, such as fruits, vegetables, herbs and other compounds, garlic has represented one of the most important sources of dietary supplements, not only for health advantages, but also for medicinal purposes for centuries. Among a large diversity of commercially available garlic supplements, AGE is more widely known and has been carefully studied. It is prepared by immersing fresh garlic in $15 \%$ aqueous ethanol solution over a prolonged period of time (up to 20 months) at room temperature (8). AGE is a commercial odorless preparation with antioxidant properties for scavenging reactive oxygen species (ROS) $(9,10)$. This natural product has been shown to possess immunomodulatory and anticancer properties. These effects have been demonstrated by in vitro and in vivo experiments; however, its mechanisms of action remain to be fully elucidated (11). It was recently demonstrated by an MTT assay that AGE induces an anti-proliferative effect on several sensitive and MDR human cancer cells (1).

A number of the beneficial effects of garlic have been shown to be attributed to various bioactive compounds isolated from garlic, including the lipid-soluble allyl sulfur compounds (e.g., diallyl sulfide, diallyl disulfide and diallyl trisulfide) and water-soluble compounds, such as $S$-allyl-L-cysteine (SAC) and $S$-allylmercaptocysteine (SAMC) (12-19). Both the organosulfur compounds, SAC and SAMC, are the major bioactive components identified in AGE (18). Recent studies have indicated that numerous natural bioactive molecules, including organosulfur compounds from Allium vegetables, have been reported to have possible preventive and therapeutic properties against certain types of cancer (20). SAC is the most abundant organosulfur compound in aged-garlic extract $(0.62 \mathrm{mg} \mathrm{SAC} / \mathrm{g}$ product) and has been used to standardize the commercial products of AGE (12). Several studies have demonstrated that SAC exhibits antioxidant properties by scavenging ROS and reactive nitrogen species (RNS), regulating oxidation-related pathways, as well as neuroprotective properties and anticancer activities (21-23). Several other studies have also demonstrated that SAC exerts anticancer effects by suppressing the cellular proliferation and metastasis, and induces apoptosis in a number of cancer models, including ovarian and prostate cancer, and hepatocellular carcinoma $(20,21,24)$. Moreover, SAC as a natural product with less side-effects, may be considered as an excellent candidate for the treatment of neuroinflammatory diseases, such as multiple sclerosis, a deleterious autoimmune and demyelinating disorder of the central nervous system (CNS) with debilitating sensory and motor complications (25-27).

In this study, mitochondrial membrane alterations of rat liver mitochondria (RLM) and the oxidation of both endogenous glutathione and endogenous pyridine nucleotides following incubation with AGE, were demonstrated. Moreover, to further examine the anti-proliferative activity of $\mathrm{SAC}$, the in vitro effects of this compound were examined by an MTT assay using the human NB cell lines, SJ-N-KP and the MYCN-amplified IMR5 cell line; the cell cycle and apoptosis were examined using PI and Annexin V-FITC labeling and flow cytometric assays. By labeling the NB cells with the probe, 5,5',6,6'-tetrachloro-1,1',3,3'-tetraethylimidacarbocyanine iodide (JC-1), cytofluorimetric analysis revealed that the target of SAC is the mitochondria, the key bioenergetic intracellular organelles, that contain a high large number of proteins macromolecules having pivotal functions.

\section{Materials and methods}

Reagents. Thiazolyl blue Tetrazolium bromide (MTT), verapamil, fetal bovine serum (FBS), 5,5'-dimethyl-oxazolidine-2,4-dione (DMO), cyclosporin A (CsA), nicotinamide adenine dinucleotide reduced form (NADH), nicotinamide adenine dinucleotide phosphate reduced form (NADPH), 5,5',6,6'-tetrachloro-1,1',3,3'-tetraethyl-imidacarbocyanine iodide (JC-1), 3,4-dimethoxybenzoic acid, hydrochloric acid, acetonitrile and sodium bicarbonate were purchased from Sigma-Aldrich. All cell culture flasks and dishes were obtained from Corning, Inc. AGE and SAC provided by Wakunaga Pharmaceutical Co. Ltd. (Hiroshima, Japan) were manufactured as follows: Garlic cloves were sliced,immersed in a water-ethanol mixture solution and naturally extracted for $>10$ months at room temperature, as previously described (28). The AGE powder used in our experiments was prepared by lyophilization. It contained approximately $28.6 \%(\mathrm{w} / \mathrm{v}, 286 \mathrm{mg} / \mathrm{ml})$ solid material, $0.63 \%$ $(6.3 \mathrm{mg} / \mathrm{ml})$ arginine and $0.1 \% \mathrm{SAC}$ (calculated on a dry weight basis) as a marker compound for standardization (29). Both SAC and the AGE powder was freshly dissolved in complete Ham's F-12 or in RPMI-1640 medium prior to each experiment. The analysis of the organosulfur compound content in the AGE powder was performed using a Shimadzu LC-6A HPLC system. The content of SAC was determined by ion-exchange chromatography, using a column TSK-GEL Amino Pak, followed by post-derivatization using o-phthalaldehyde (OPA), and a fluorescent detection with excitation at $340 \mathrm{~nm}$ and emission at $455 \mathrm{~nm}$. The test samples for the analysis of SAC were prepared by the addition of 5\% trichloroacetic acid, as previously described (30). The SAC powder was freshly dissolved in RPMI-1640 medium supplemented with $10 \%$ FBS, normally up to $50 \mathrm{mg} / \mathrm{ml}$, prior to each experiment. During the experiment the solution, which was kept in the dark, was for one use only.

Cells and cell culture. Two types of NB cells were used in this study. One was the SJ-N-KP cells, a non-amplified NB cell line and the second one was the IMR5 cells, a n-myc amplified NB cell line (31). Both cell lines were a kind gift from Dr N. Crescenzio (Department of Paediatrics, University of Turin, Regina Margherita Children's Hospital, Turin, Italy) and Dr F. Timeus (Paediatric Haematology-Oncology, 
Regina Margherita Children's Hospital) (31). The NB cell lines, SJ-N-KP and IMR5 were maintained in monolayer cultures in RPMI-1640 medium supplemented with $10 \% \mathrm{FBS}$, $2 \mathrm{mM}$ L-glutamine, $100 \mu \mathrm{g} / \mathrm{ml}$ streptomycin and $100 \mathrm{IU} / \mathrm{ml}$ penicillin (31). Both cell lines were incubated in a humidified atmosphere of $5 \% \mathrm{CO}_{2}$ in a water-jacketed incubator at $37^{\circ} \mathrm{C}$. For each passage, exponentially growing SJ-N-KP and IMR5 cells were harvested with $10 \mathrm{mM}$ EDTA and by the further addition of $0.10 \%$ trypsin solution. The trypsin activity was quenched by the addition of complete RPMI-1640 medium (31).

Determination of apoptotic cell death by Annexin V-FITC staining. To detect phosphatidylserine residue exposure on the surface of the plasma membrane of the tumor cells in the initial step of apoptosis, an Annexin V-FITC apoptosis detection kit was used as previously described by Van Engeland et al (32). The NB cell lines, SJ-N-KP and IMR5 $\left(9.1 \times 10^{4}\right.$ cells $\left./ \mathrm{ml}\right)$, were seeded in a 6-well plate, containing complete RPMI-1640 medium and incubated for $24 \mathrm{~h}$ at $37^{\circ} \mathrm{C}$ to allow for the the complete reattachment of the cells to the plates. After exchanging the medium with fresh medium, the cells were incubated at $37^{\circ} \mathrm{C}$ in the presence of 0,10 and $20 \mathrm{mM} \mathrm{SAC}$ for $48 \mathrm{~h}$. Following incubation at $37^{\circ} \mathrm{C}$, the cells were detached, washed with PBS, centrifuged at $400 \mathrm{xg}$ for $2 \mathrm{~min}$ at $25^{\circ} \mathrm{C}$ and then stained with $1 \mu \mathrm{g} / \mathrm{ml}$ of Annexin V-FITC and with $1 \mu \mathrm{g} / \mathrm{ml}$ of PI for $10 \mathrm{~min}$ at room temperature in the dark. Annexin V-FITC and PI fluorescence were measured on the FL-1 channel $(533 / 30 \mathrm{~nm})$ and the FL-3 channel (>670 nm), respectively, with excitation at $488 \mathrm{~nm}$. A minimum of 10,000 events/sample was acquired (32).

Cell cycle analysis. Cell cycle distribution was analyzed by labeling the cells with PI. The assays were carried out as previously described by Nicoletti et al (33). S-allyl-L-cysteine-treated and the untreated NB cell lines, SJ-N-KP and IMR5 $\left(9.1 \times 10^{4}\right.$ cells $\left./ \mathrm{ml}\right)$, as described above in Annexin V-FITC labeling, were harvested, washed twice with cold PBS and centrifuged at $400 \mathrm{x}$ g for $2 \mathrm{~min}$ at $4^{\circ} \mathrm{C}$. The pellet was fixed in $70 \%$ ethanol at $-20^{\circ} \mathrm{C}$ for $1 \mathrm{~h}$. After washing twice with PBS, the cells were resuspended in PBS containing $100 \mu \mathrm{g} / \mathrm{ml}$ RNase A and $40 \mu \mathrm{g} / \mathrm{ml} \mathrm{PI}$. Following incubation at $37^{\circ} \mathrm{C}$ for $1 \mathrm{~h}$, the cells were subsequently analyzed by flow cytometry using the FL-3 channel $(>670 \mathrm{~nm})$ with the acquisition of 10,000 events/sample.

SAC dose response assay. The NB cell lines, SJ-N-KP and IMR5, were seeded in a 96-well plate and incubated for $24 \mathrm{~h}$ to allow for the complete reattachment of the cells to the plates. After the medium was replaced with fresh medium, the cells were incubated in the presence of $0,1,5,10,20$ and $30 \mathrm{mM}$ $\mathrm{SAC}$ for $48 \mathrm{~h}$. The anti-proliferative effects of SAC on the human NB cells were examined by MTT assay. Briefly, MTT was added to each well at a final concentration of $0.5 \mathrm{mg} / \mathrm{ml}$. Following $3 \mathrm{~h}$ of incubation at $37^{\circ} \mathrm{C}$, dimethyl sulfoxide was added to dissolve the crystals. The absorbance was determined at 577 and $660 \mathrm{~nm}$ using a spectrophotometer multi-mode plate reader [Synergy HT BioTek, serial no. 270204; BioTek, Bernareggio (MB)].

Measurements 'in situ' of mitochondrial membrane potential $(\Delta \psi m)$. The changes in $\Delta \psi \mathrm{m}$ in whole cells were assayed using the lipophilic cationic probe, JC-1 dye. The NB cell lines, SJ-N-KP and IMR5, were seeded in a 12-well plate and incubated for $24 \mathrm{~h}$ at $37^{\circ} \mathrm{C}$ to allow the cells to adhere to the plates. After the medium was replaced with fresh medium, the cells were incubated with 30 and $50 \mathrm{mM}$ of SAC for $24 \mathrm{~h}$ at $37^{\circ} \mathrm{C}$. Subsequently, the cells were stained with $2.5 \mu \mathrm{g} / \mathrm{ml}$ of JC-1 for $20 \mathrm{~min}$ at $37^{\circ} \mathrm{C}$. The detached cells were washed with PBS and then resuspended in PBS. The samples were then analyzed using a BD Accuri C6 flow cytometer (BD Biosciences). JC-1 was excited using an argon laser at a wavelength of $488 \mathrm{~nm}$ (using a BD Accuri C6 flow cytometer). The emitted green (JC-1 monomer) and red (JC-1 aggregate) fluorescence were detected at the FL-1 channel $(533 / 30 \mathrm{~nm})$ and FL-2 channel $(585 / 40 \mathrm{~nm})$, respectively. At least 10,000 events/sample were acquired in log mode. The ratio of red (FL2)/green (FL1) fluorescence intensity was used to represent the $\Delta \psi \mathrm{m}$.

Gas chromatography-mass spectrometry (GC-MS) analysis of $A G E$ and $S A C$. SAC was analyzed by GC-MS as its tert-butyldimethylsilyl (TBDMS) derivative according to Jiménez-Martín et al (34). Briefly, a $20 \mu \mathrm{l}$ aliquot of a solution containing SAC at $1 \mathrm{mg} / \mathrm{ml}$ in $0.1 \mathrm{~N} \mathrm{HCl}$ spiked with $15 \mu 1$ internal standard (3,4-dimethoxybenzoic acid, $0.1 \mathrm{mg} / \mathrm{ml}$ ) was dried, and $50 \mu \mathrm{l}$ of neat $N$-tert-butyldimethylsilyl- $N$-methyltrifluoroacetamide (MTBSTFA), followed by $50 \mu \mathrm{l}$ of acetonitrile, were added. The mixture was heated at $100^{\circ} \mathrm{C}$ for $2 \mathrm{~h}$. The sample was then neutralized with sodium bicarbonate and subjected to GC-MS analysis. The same derivatization protocol was used for AGE power $(1 \mathrm{mg} / 0.1 \mathrm{M} \mathrm{HCl})$. GC-MS analyses were performed with an Agilent 7890B gas chromatograph coupled to a 5977B quadrupole mass selective detector (Agilent Technologies). Chromatographic separations were carried out with an Agilent HP5 ms fused-silica capillary column (30 m x $0.25 \mathrm{~mm}$ i.d.) coated with 5\%-phenyl-95\%-dimethylpolysiloxane (film thickness, $0.25 \mu \mathrm{m}$ ) as a stationary phase. The injection mode was splitless at a temperature of $280^{\circ} \mathrm{C}$, the column temperature program was $70^{\circ} \mathrm{C}(1 \mathrm{~min})$ then to $300^{\circ} \mathrm{C}$ at a rate of $20^{\circ} \mathrm{C} / \mathrm{min}$ and held for $10 \mathrm{~min}$. The carrier gas was helium at a constant flow of $1.0 \mathrm{ml} / \mathrm{min}$. The spectra were obtained in the electron impact mode at $70 \mathrm{eV}$ ionization energy; ion source $280^{\circ} \mathrm{C}$; ion source vacuum $10^{-5}$ Torr. MS analysis was performed simultaneously in TIC (mass range scan from m/z 50 to 600 at a rate of 0.42 scans/sec) and SIM mode. GC-SIM-MS analysis was performed selecting the following ions: $\mathrm{m} / \mathrm{z} 302$ and $\mathrm{m} / \mathrm{z} 332$ for SAC and m/z 239 for 3,4-dimethoxybenzoic acid (internal standard).

Animals. A total of 50 male Wistar rats, 2 months old, weighing approximately $150 \mathrm{~g}$, were used in our experiments. The rats, housed in the animal facility of the Department of Biomedical Sciences, University of Padova, were maintained under controlled conditions (temperature $20-22^{\circ} \mathrm{C}$, relative humidity 48-50\%, water with antibacterial control and a 12:12 h light/dark cycle) and provided with water and a standard diet (4RF25) purchased by Mucedola s.r.l., Settimo Milanese (MI) according to Ohkubo et al (1). The experimental procedures were approved by the local Ethics Committee for Animal Experimentation (CEASA) (protocol no. 3619, 15.1.2014) and performed in agreement with the international guidelines, 
as well as European Communities Council Directive and National Regulations (CEE Council 86/609 and DL 116/92).

RLM isolation and purification. Rat liver mitochondria (RLM) were isolated by the differential centrifugation method according to Ohkubo et al (1). In detail, the rats were starved overnight and sacrificed by cervical dislocation. The livers were rapidly explanted, immersed in ice-cold isolation medium containing $250 \mathrm{mM}$ sucrose, $5 \mathrm{mM}$ HEPES (pH 7.4), $0.5 \mathrm{mM}$ EGTA and washed 4/5 times with the same medium. The livers were minced into small sections and washed with ice-cold fresh medium without EGTA. The suspension was transferred to a glass potter and homogenized using a Teflon pestle operating at 1,600 rpm, by 3-4 strokes. The homogenate was centrifuged at $700 \mathrm{x} \mathrm{g}$ for $5 \mathrm{~min}$ at $4^{\circ} \mathrm{C}$ and the obtained supernatant was centrifuged at $10,800 \mathrm{xg}$ for $10 \mathrm{~min}$ at $4^{\circ} \mathrm{C}$. The pellet was washed with isolation medium, resuspended and centrifuged at $15,900 \mathrm{x}$ g for $10 \mathrm{~min}$ at $4^{\circ} \mathrm{C}$. Finally, the obtained pellet, containing the mitochondria, was suspended in the standard medium (see the incubation procedure) (35). Mitochondrial proteins were measured by the biuret method with BSA, as a standard (36). The mitochondria (1 mg protein $/ \mathrm{ml}$ ) were incubated in a water-jacketed cell at $25^{\circ} \mathrm{C}$ under continuous stirring. The standard medium contained $250 \mathrm{mM}$ sucrose, $10 \mathrm{mM}$ HEPES (pH 7.4), $5 \mathrm{mM}$ Na-succinate, $1.25 \mu \mathrm{m}$ rotenone and $1 \mathrm{mM}$ Na-phosphate. Variations and/or other additions are provided with each experiment.

Determination of mitochondrial functions. Mitochondrial membrane potential $\left(\Delta \Psi_{\mathrm{m}}\right)$ was calculated by detecting the distribution of the lipid-soluble cation tetraphenylphosphonium ( $\mathrm{TPP}^{+}$, Sigma-Aldrich) through the inner membrane, measured by a $\mathrm{TPP}^{+}$selective electrode, according to Kamo et al (37). The mitochondrial electrochemical gradient $\left(58 \Delta \mathrm{pH}_{\mathrm{m}}\right)$ was calculated from the distribution of DMO $\left(\left[{ }^{14} \mathrm{C}\right] 5,5\right.$-dimethyl-oxazolidine-2,4-dione) across the mitochondrial membrane, according to Rottemberg (38). 58 is the value in $\mathrm{mV}$ of $\mathrm{RT} / \mathrm{zF}$ for giving the $\Delta \mathrm{pH}$ value in $\mathrm{mV}$. The redox state of mitochondrial glutathione was detected by using the Ellman reagent, according to Tietze (39). The change with time of the redox state of mitochondrial pyridine nucleotides was followed fluorometrically in an Aminco Bowman 4-8202 spectrofluometer with excitation at $354 \mathrm{~nm}$ and emission at $462 \mathrm{~nm}$.

Statistical analysis. The data were presented as the means \pm SEM or means \pm SD. Statistical analysis was performed using one-way ANOVA with the Dunnett's post hoc test, in EZR (Kanda) (40). A P-value $<0.05$ was considered to indicate a statistically significant difference.

\section{Results}

Mitochondrial membrane alterations of RLM following incubation with AGE. Fig. 1 shows the effects of AGE on the components of the electrochemical gradient $\left(\Delta \mu_{\mathrm{H}}{ }^{+}\right)$, membrane potential, $\Delta \Psi_{\mathrm{m}}$, and the chemical gradient, $\Delta \mathrm{pH}_{\mathrm{m}}$, expressed in $\mathrm{mV}$. The results revealed that under normal conditions, both the $\Delta \Psi_{\mathrm{m}}$ and $58 \Delta \mathrm{pH}_{\mathrm{m}}$ exhibited the physiological values of 170 and $40 \mathrm{mV}$, respectively. The presence of AGE induced an initial increase in $\Delta \Psi_{\mathrm{m}}$ of approximately $30 \mathrm{mV}$ and a corresponding

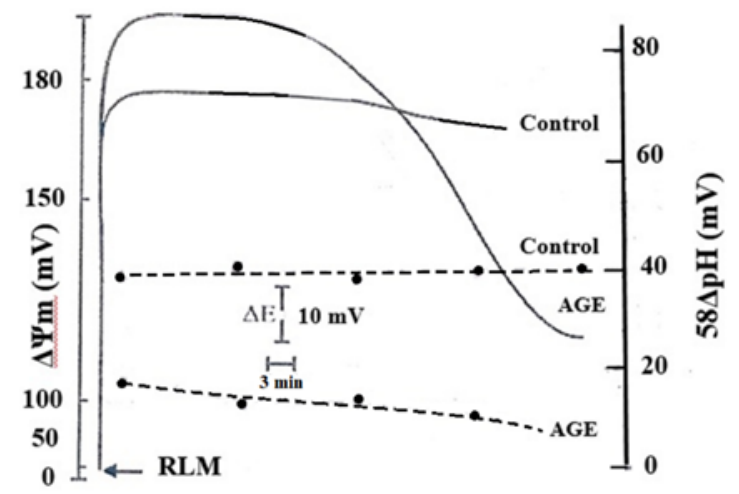

Figure 1. Effect of AGE on the components of the $\Delta \mu_{\mathrm{H}}{ }^{+}, \Delta \Psi_{\mathrm{m}}$ and $\Delta \mathrm{pH}_{\mathrm{m}}$ RLM were incubated in standard medium as described in the Materials and methods section supplemented with $2 \mu \mathrm{M}$ TPP for detecting $\Delta \Psi_{\mathrm{m}}$ and with $400 \mu \mathrm{M}\left[{ }^{14} \mathrm{C}\right] \mathrm{DMO}(1 \mu \mathrm{Ci} / \mathrm{mmol})$ plus $5 \mathrm{mM}\left[{ }^{3} \mathrm{H}\right]$ glycerol $(100 \mu \mathrm{Ci} / \mathrm{mmol})$ for detecting $58 \Delta \mathrm{pH}_{\mathrm{m}}$. Where indicated, $2 \mathrm{mg} / \mathrm{ml} \mathrm{AGE}$ was present. Both measurements of $\Delta \Psi_{\mathrm{m}}$ and $\Delta \mathrm{pH}_{\mathrm{m}}$ were performed on the same sample. A representative experiment is shown. Five other experiments yielded almost identical results. AGE, aged garlic extract; $\Delta \mu_{\mathrm{H}}{ }^{+}$, electrochemical gradient; $\Delta \Psi_{\mathrm{m}}$, mitochondrial membrane potential; $\Delta \mathrm{pH}_{\mathrm{m}}$, mitochondrial electrochemical gradient.

identical decrease in $58 \Delta \mathrm{pH}_{\mathrm{m}}$. However, after approximately $15 \mathrm{~min}$, the $\Delta \Psi_{\mathrm{m}}$ gradually decreased until $120 \mathrm{mV}$. In addition, the $58 \Delta \mathrm{pH}_{\mathrm{m}}$ value underwent a parallel drop of approximately $10 \mathrm{mV}$. The membrane alterations of RLM by AGE are shown in Fig. 1. The decrease in both $\Delta \Psi_{\mathrm{m}}$ and $58 \Delta \mathrm{pH}_{\mathrm{m}}$ was accompanied by an increase in the oxidation of endogenous glutathione content. This is evidenced by the decrease in the reduced content of glutathione induced by different concentration of AGE as reported in Fig. 2. AGE also caused the oxidation of endogenous pyridine nucleotides, NADH and NADPH, as observed by the downward deflection of the curves detecting the reduced state of these nucleotides in Fig. 3. It is also to evidence that cyclosporine A (CsA) strongly inhibits the oxidation of both demetabolites.

$G C-M S$ analysis of $A G E$ and $S A C$. In this study, we evaluated the use of the silylation reagent, MTBSTFA, for the derivatization of SAC. MTBSTFA derivatives are more stable and less moisture-sensitive than those formed using lower molecular weight reagents. A chromatogram of SAC is presented in Fig. 4. In the chromatographic condition described above, SAC has a retention time of 9,8 min and an electron impact mass spectrum (Fig. 4, inset) showing a typical fragment (m/z 302) corresponding to the molecular weight of the derivative less $\mathrm{C}_{3} \mathrm{H}_{5} \mathrm{~S}$ (M-73). In Fig. 5, a typical GC-MS chromatogram of AGE is presented. The chromatogram shows the presence of a peak having the same retention time and mass spectrum of SAC. In addition, TBDMS derivatization allows for the identification of in AGE a number of polar compounds, including amino acids and carboxylic acids. Amino acid derivatives were identified by comparing spectral data with those reported in the NIST2018 library. Electron impact spectra of these derivatives contain typical fragments corresponding to the molecular weight of the derivative less $\mathrm{CH}_{3}(\mathrm{M}-15), \mathrm{C}_{4} \mathrm{H}_{9}$ (M-57), $\mathrm{C}_{4} \mathrm{H}_{9}+\mathrm{CO}$ (M-85) and CO-O-TBDMS (M-159).

Anti-proliferative effects of SAC on the human NB cell lines, $S J-N-K P$ and IMR-5. The results of MTT assays revealed 


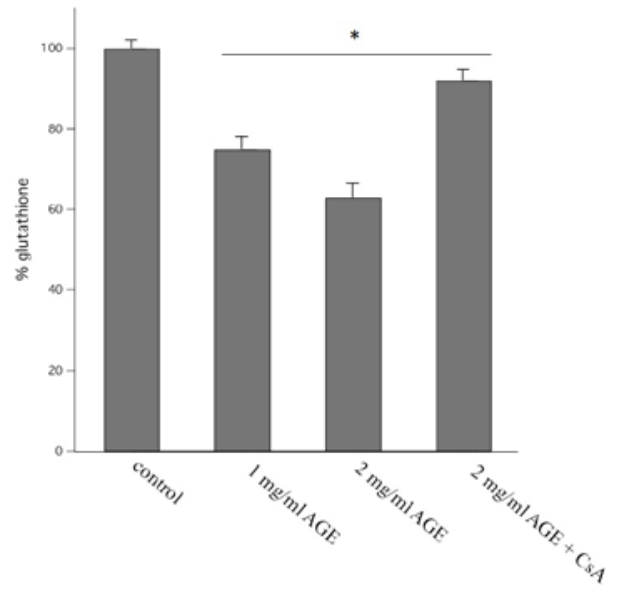

Figure 2. Redox state of mitochondrial glutathione in the presence of AGE. RLM were incubated for $30 \mathrm{~min}$ in standard medium as described in the Materials and methods section. AGE concentrations are indicated in the figure. When present, $1 \mu \mathrm{M}$ CsA. Results are the mean values $\pm \mathrm{SD}$ of 5 experiments. Data were analyzed by one-way ANOVA, followed by Dunnett's post hoc test. Statistically significant differences $\left({ }^{*} \mathrm{P}<0.05\right)$ are indicated by asterisks. AGE, aged garlic extract; RLM, rat liver mitochondria.

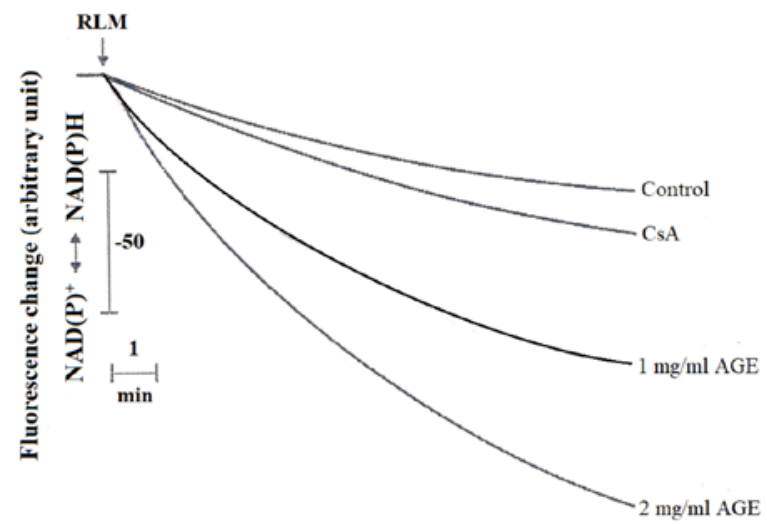

Figure 3. Changes in the redox state of mitochondrial pyridine nucleotides in the presence of AGE. RLM were incubated for $30 \mathrm{~min}$ in standard medium as described in the Materials and methods section. AGE concentrations are indicated in the figure. When present, $1 \mu \mathrm{M} \mathrm{CsA}$. A typical experiment is reported, 4 others yielded identical results. AGE, aged garlic extract; RLM, rat liver mitochondria.

that treatment with SAC exerted anti-proliferative effects on the NB cancer cells examined in a dose-dependent manner. Treatment with $20 \mathrm{mM}$ of SAC for $48 \mathrm{~h}$ decreased the viability of both the SJ-N-KP and IMR-5 cells to 30.05 and $33.58 \%$, respectively, when compared with the untreated control cells (Fig. 6). The proliferation of both cell lines was already markedly decreased to approximately $63.77 \%$ of the control level following treatment with $5 \mathrm{mM} \mathrm{SAC}$ for the same incubation time of $48 \mathrm{~h}$ (Fig. 6). A further extension of the incubation time at $72 \mathrm{~h}$, did not considerably affect the viability of the cells (data not shown). A concentration of $<5 \mathrm{mM} \mathrm{SAC}$ exerted a modest effect of about $10 \%$ only on the IMR- 5 cells.

Analysis of the induction of apoptosis by flow cytometry. The loss of phospholipid asymmetry and the appearance of phosphatidylserine residues on the outer layer of the plasma

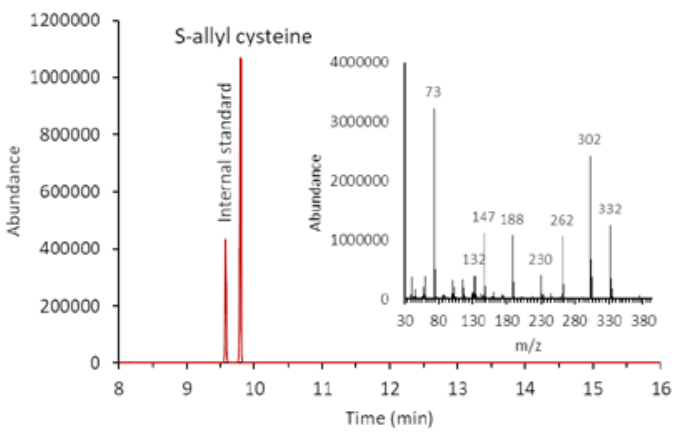

Figure 4. GC-MS chromatogram of SAC. SAC and internal standard were analyzed as TBDMS-derivatives. The inset presents the electron impact mass spectrum of SAC bearing two TBDMS-groups. GC-MS, gas chromatography-mass spectrometry; SAC, S-allyl-L-cysteine; TBDMS, tert-butyldimethylsilyl.

membrane is an early signal of cell death, namely apoptosis. Annexin $\mathrm{V}$ is a $\mathrm{Ca}^{2+}$-dependent phospholipid-binding protein with a high affinity for phosphatidylserine. In this study, to detect externalized phosphatidylserine, Annexin V-FITC/PI staining was performed in the NB cell lines, SJ-N-KP and IMR5. The results of flow cytometric analysis are presented in Fig. 7. Treatment with 10 and $20 \mathrm{mM}$ of SAC increased the percentage of the total apoptotic cells (Fig. 7A, middle and upper right panels) to 18.1 and $42.6 \%$, respectively, compared with the untreated SJ-N-KP cells (5.2\%) (Fig. 7A, upper left panel). On the contrary, the percentage of apoptotic cells was higher in the IMR5 cells than the SJ-N-KP cells following treatment with 10 and $20 \mathrm{mM}$ of SAC (Fig. 7A, lower panels, 33.0 and $51.7 \%$, respectively, and Fig. 7B), compared with the untreated IMR5 cells (6.2\%) (Fig. 7A, lower left panel).

To confirm the involvement of apoptotic cell death induced by SAC, flow cytometric analysis using PI staining was performed to analyze the cell cycle status. The apoptotic cells that undergo DNA fragmentation exhibit sub-G1 DNA contents. The exposure of the NB cell lines, SJ-N-KP and IMR5, to 10 and $20 \mathrm{mM}$ of SAC for $48 \mathrm{~h}$ induced a significant increase in the sub-G1 apoptotic cell population, compared to that observed in the untreated control cells (Fig. 8). The percentage of treated IMR5 cells in the sub-G1 phase (38.9 and 67,7\%) was higher than the percentage of SJ-N-KP cells in the same phase (24.0 and $44.8 \%)$, at both concentrations of SAC, which was consistent with the results of the Annexin V-FITC/PI staining assay (Fig. 7). These results confirm the cytotoxicity induced by both concentrations (10 and $20 \mathrm{mM}$ ) of SAC and suggest the involvement of an apoptotic mechanism.

Depolarization of $\triangle \psi m$ induced by SAC in the NB SJ-N-KP and IMR 5 cell lines. To investigate the mechanisms through which SAC induces cell death, we examined the loss of $\Delta \psi \mathrm{m}$ using a flow cytometric analysis of the control and treated cells loaded with the mitochondrial probe, JC-1. In healthy cells, membrane-permeable JC- 1 dye spontaneously accumulates in the mitochondria and forms aggregates known as $\mathrm{J}$-aggregates that emit red fluorescence after excitation. By contrast, in apoptotic cells, with a low $\Delta \psi \mathrm{m}, \mathrm{JC}-1$ remains in the cytoplasm as monomers, which emit green fluorescence. 


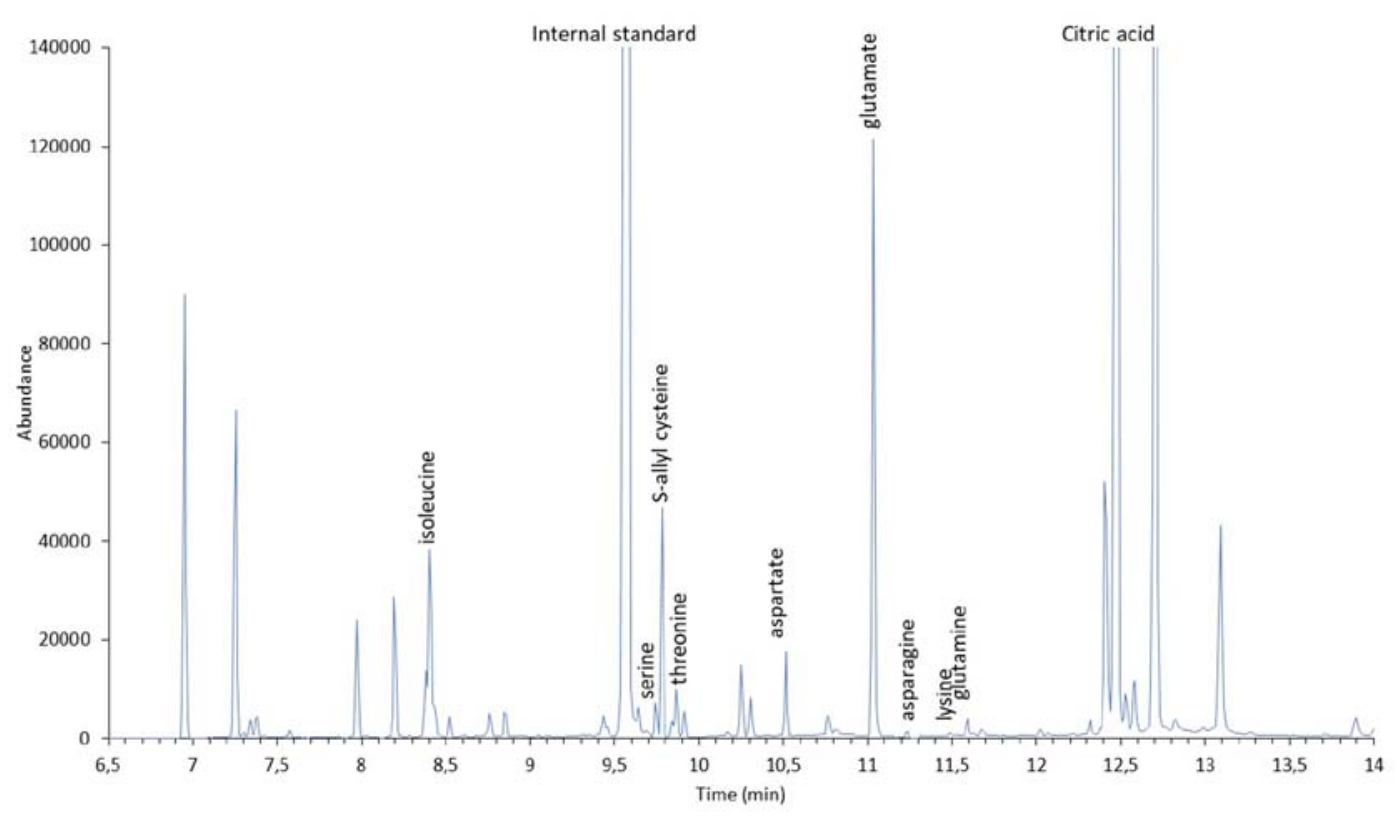

Figure 5. GC-MS chromatogram of AGE. GC-MS, gas chromatography-mass spectrometry; AGE, aged garlic extract.
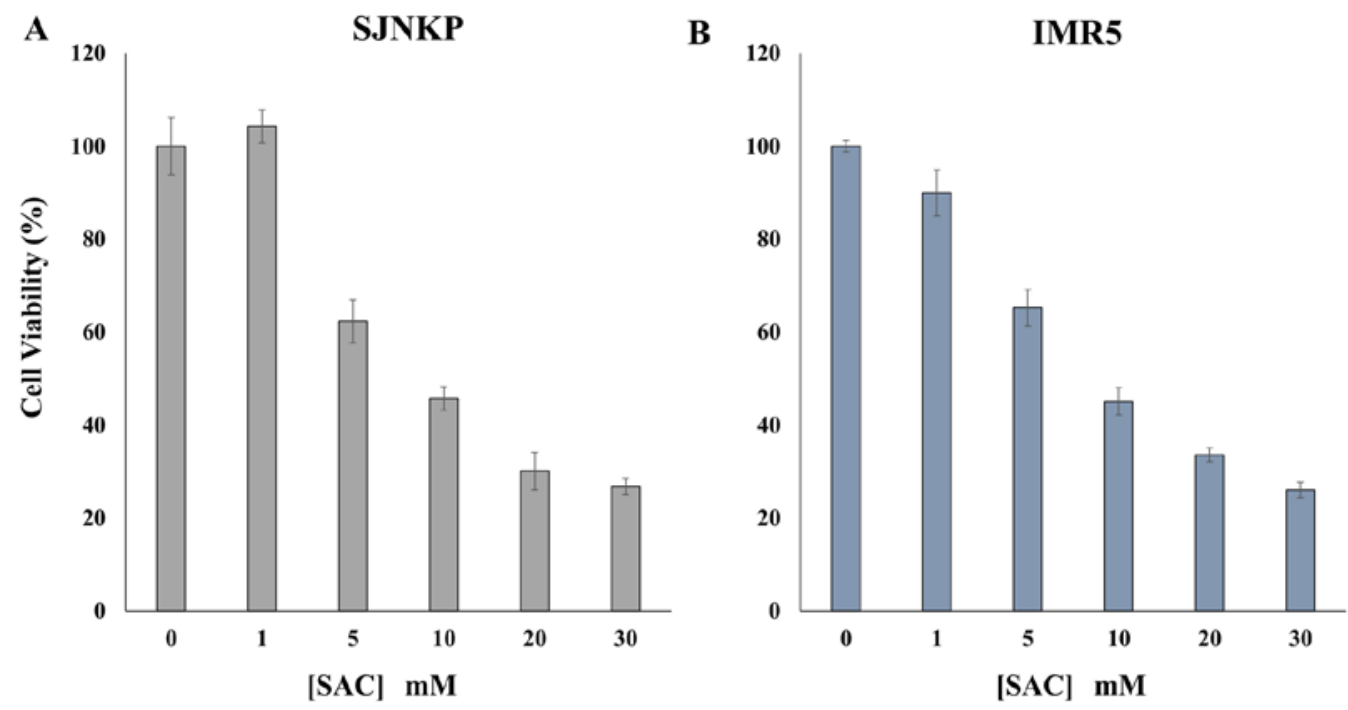

Figure 6. (A and B) Anti-proliferative effects of SAC on human neuroblastoma cell lines. (A) SJ-N-KP and (B) IMR5 cells were treated with 0, 1, 5, 10, 20 and $30 \mathrm{mM}$ of SAC alone for $48 \mathrm{~h}$. The effects were determined by MTT assay. Each point represents the mean \pm SEM of 2 independent experiments, with 3 wells per experiment. Where not shown, error bars lie within symbols. Data represent the means \pm SD. SAC, S-allyl-L-cysteine.

Therefore, the loss of $\Delta \psi \mathrm{m}$ is indicated by a decrease in the ratio of red/green fluorescence intensity. As shown in Fig. 9, in both the NB cell lines SJ-N-KP and IMR5, exposure to SAC induced an evident MMD. Treatment with SAC increased the ratio green/red fluorescence intensity and concomitantly decreased the red fluorescence intensity in a dose-dependent manner. The SAC-induced $\Delta \psi \mathrm{m}$ dissipation was more evident in the IMR 5 cells than the SJ-N-KP cells following treatment with $50 \mathrm{mM} \mathrm{SAC}$ solutions for $48 \mathrm{~h}$ at $37^{\circ} \mathrm{C}$ (average 46.6 and $59.1 \%$, respectively). Moreover, a decrease in MMD was already observed in the IMR5 cells at lower concentrations of SAC, $30 \mathrm{mM}$, whereas the same concentration of SAC did not induce any variations in the SJ-N-KP cells, as shown in Fig. 9.

\section{Discussion}

Therapeutic approaches based on isolated compounds obtained from natural products to handle central and peripheral disorders involving oxidative stress and inflammation are more common nowadays. Among the natural compound, garlic, a species of the Allium genus, has been used throughout recorded history for both culinary and medicinal purposes $(20,21,24)$. In our previous study, as well as in numerous other reports, it was observed that AGE induced a decrease in the viability of several human cancer cell lines $(1,20,24,41)$. This result represents an interesting finding, since in conventional cancer chemotherapy, numerous issues hamper successful treatment. Therefore, the development of more effective and less toxic 
A

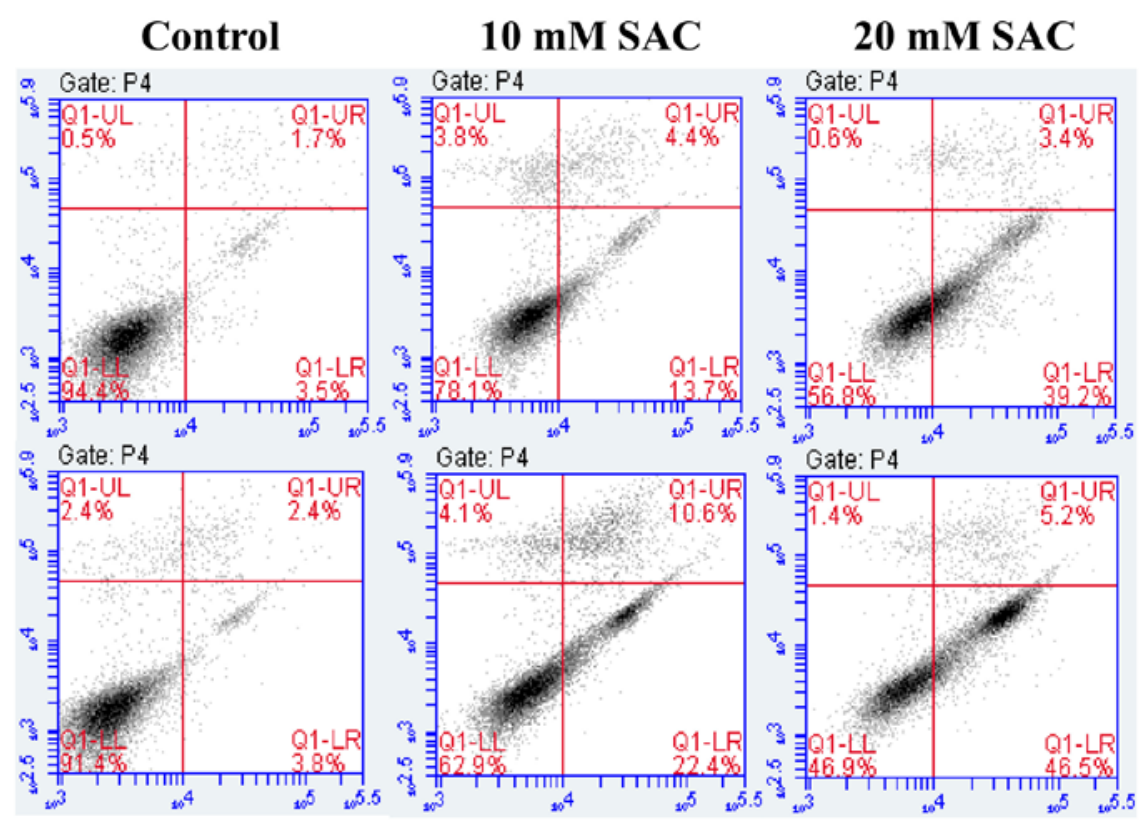

Annexin V-FITC

B

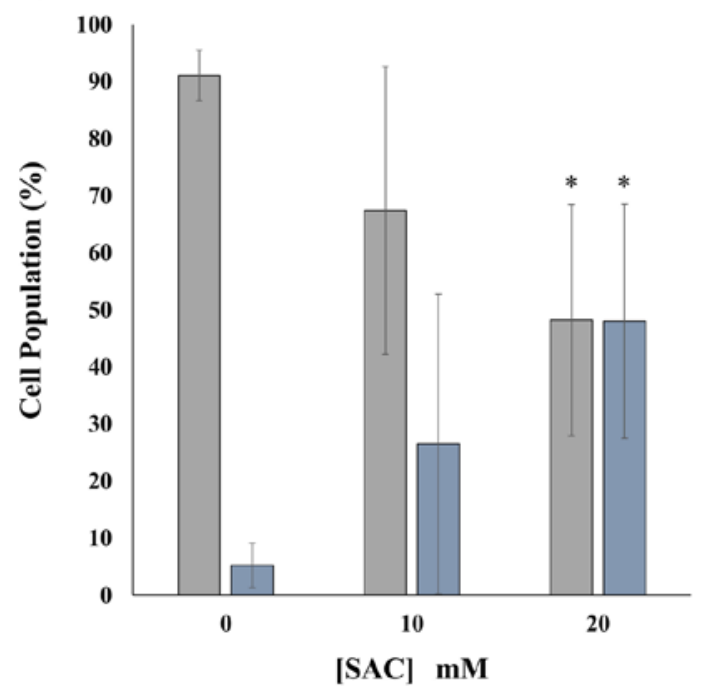

IMR5

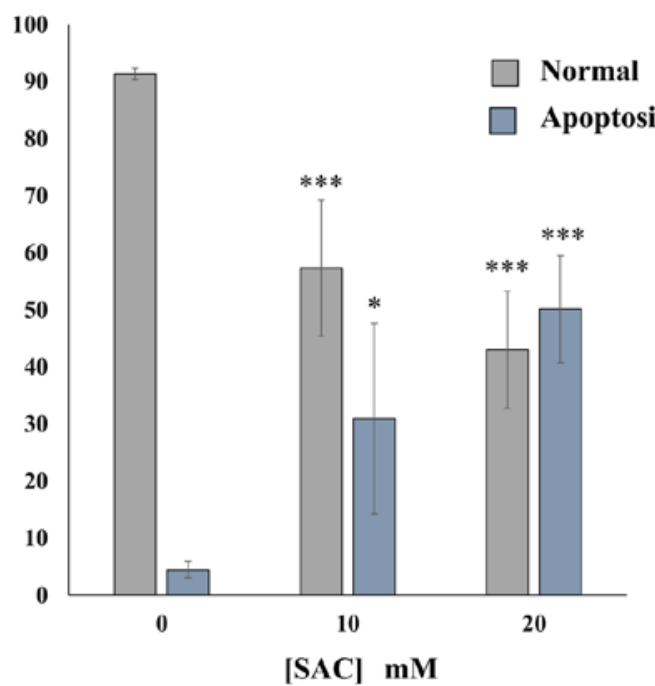

Figure 7. Annexin V/PI assay: Effect of SAC on SJ-N-KP and IMR5 cells. Flow cytometric analysis of apoptosis of neuroblastoma cells following double labeling with Annexin V-FITC and PI. Neuroblastoma cells were treated with increasing concentrations (0, 10 and $20 \mathrm{mM})$ of SAC. At $48 \mathrm{~h}$ after the end of the treatment, and incubation at $37^{\circ} \mathrm{C}$, cells were analyzed by flow cytometry. (A) Representative Annexin V-FITC and PI flow cytometry dot plots of SJ-N-KP and IMR5 cells are shown. The X-axis represents FITC staining, and the y-axis represents PI staining. The percentage of cells displaying Annexin V-FITC positive/PI-negative (early apoptosis), Annexin V-FITC positive/PI-positive (late apoptotic or dead), Annexin V-FITC negative/PI-positive (necrotic) and double negative cells (viable cells) is indicated. The dot plots profile of cells were obtained from 1 out of 2 independent experiments, performed in the same experimental conditions, which yielded similar results. (B) Each bar represents the mean \pm SD of normal or total apoptotic cells of 2 independent experiments. Data were analyzed by one-way ANOVA, followed by a Dunnett's post hoc test. (A) ${ }^{*} \mathrm{P}<0.05$ vs. control SJ-N-KP cells; and (B) ${ }^{*} \mathrm{P}<0.05$ and ${ }^{* * *} \mathrm{P}<0.001$ vs. control IMR5 cells. SAC, S-allyl-L-cysteine.

therapeutic regimens is vital for the improvement of survival of patients with cancer. Our previous study revealed that the treatment of a gastric adenocarcinoma cell line (AGS), a human cervical adenocarcinoma cell line (HeLa), a melanoma cell line (M14), a human colon adenocarcinoma cell line (LoVo WT) and its MDR variant (LoVo DX) cells with AGE was accompanied by characteristic mitochondrial alterations, intracellular organelles that represent the bioenergetic key (1). The mitochondrial probe JC-1 dye exposure on the outer surface of the mitochondrial membrane, clearly revealed the onset of the MMD process. In general, the mitochondrial dysfuntions of the above-mentioned WT cell lines and the resistant phenotype mirrored the results of the cell survival experiments. In addition, it was observed that AGE acts in the RLM as a $\mathrm{K}^{+} / \mathrm{H}^{+}$antiporter that directly affects some mitochondrial bioenergetic functions. In fact, the prolonged incubation of the RLM with AGE induced depolarization and matrix swelling, typical alterations of mitochondrial permeability transition phenomenon (1). Further new findings reported in this study, demonstrated that AGE, during the first 15 min of incubation, 
A

SJNKP

IMR5

B

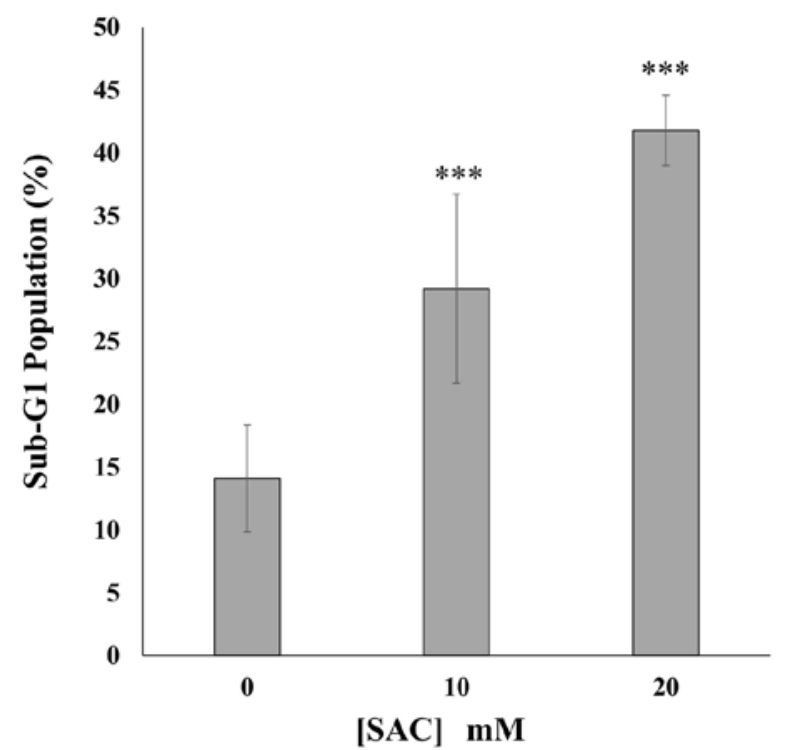

10 mM SAC

PI
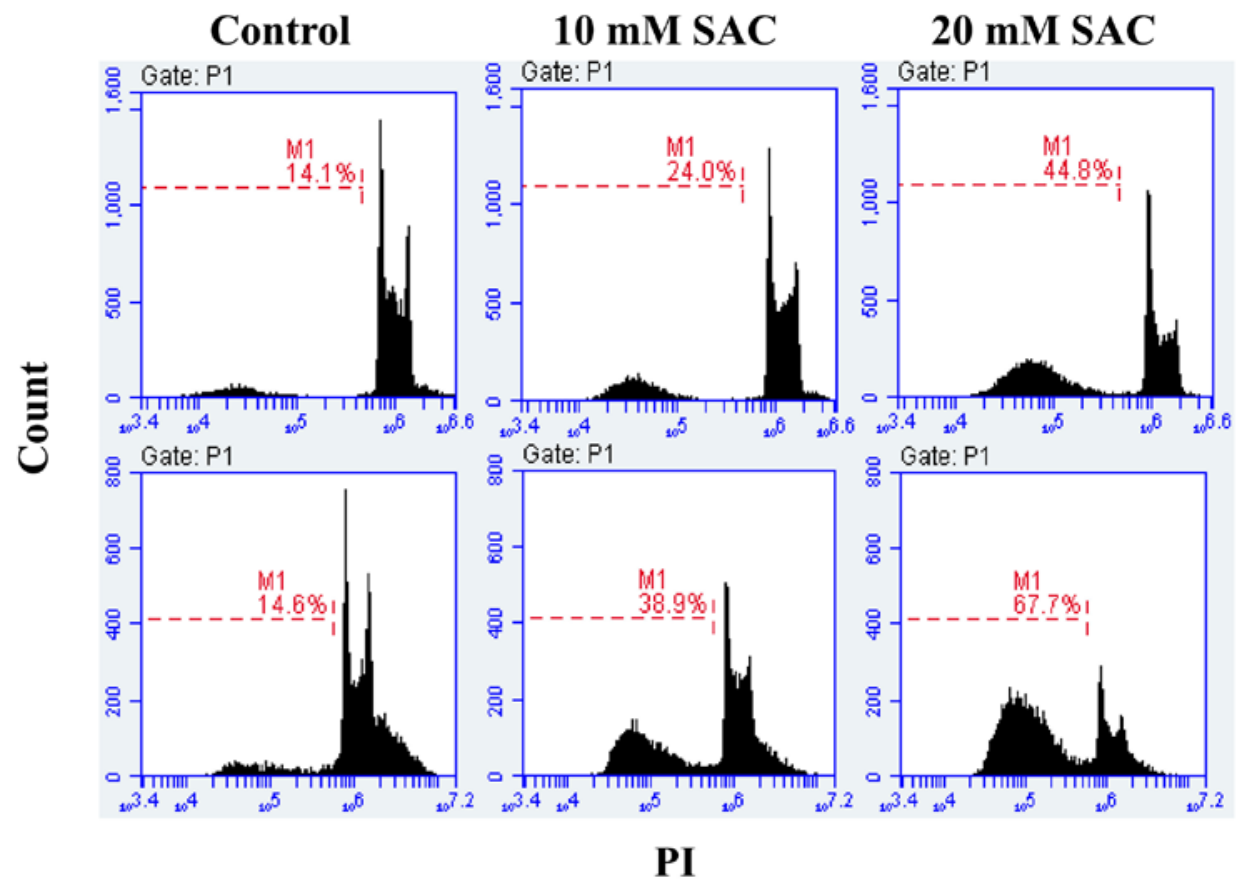

IMR5

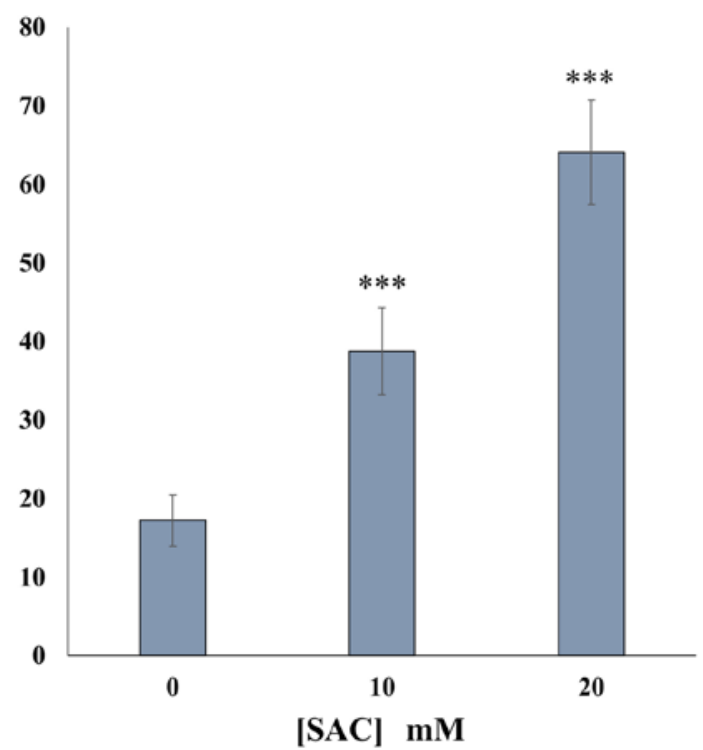

Figure 8. Cell cycle assay: Effect of SAC on SJ-N-KP and IMR5 cells. Cell cycle analysis carried out by flow cytometry on neuroblastoma cells. SJ-N-KP and IMR5 cells were treated with increasing concentrations $(0,10$ and $20 \mathrm{mM})$ of SAC. At $48 \mathrm{~h}$ after the end of the treatment, and incubation at $37^{\circ} \mathrm{C}$, followed by the staining with PI and RNase, the cells were analyzed by flow cytometry. (A) Representative histograms of sub-G1 analysis performed on SJ-N-KP and IMR5 cells using PI staining are shown. The percentage of the sub-G1 cell population is indicated. The histograms have been obtained from 1 out of 2 experiments carried out in the same experimental conditions, which gave similar results. (B) Each bar represents the mean \pm SD of sub-G1 cell population of 2 independent experiments. Data were analyzed by one-way ANOVA, followed by Dunnett's post hoc test. ${ }^{* * *} \mathrm{P}<0.001$ vs. control SJ-N-KP or IMR5 cells. SAC, S-allyl-L-cysteine.

functioned as a typical activator of the $\mathrm{K}^{+} / \mathrm{H}^{+}$exchanger, as mentioned above. This was demonstrated by the increase in $\Delta \Psi_{\mathrm{m}}$ induced by AGE, that exhibited a similar effect of the typical $\mathrm{K}^{+} / \mathrm{H}^{+}$ionophores, nigericin and salinomycin as previously demonstrated (1). The decrease in $\Delta \Psi_{\mathrm{m}}$ and $58 \Delta \mathrm{pH}_{\mathrm{m}}$ triggered after $15 \mathrm{~min}$ of incubation, was accompanied by the oxidation of both endogenous glutathione and endogenous pyridine nucleotides (Figs. 2 and 3). The oxidation process can be explained as reported in our previous study (1). These results demonstrate that the collapse in the $\Delta \mu \mathrm{H}^{+}$is indicative of a general oxidative stress induced by AGE, leading to the phenomenon of mitochondrial permeability transition and potentially triggering of apoptotic pathway in the cell. The induction of MPT is strongly supported by the prevention of the oxidation of both glutathione and pyridine nucleotides exhibited by CsA, well known typical inhibitor of MPT. Moreover, these data indicate that AGE is able to cause oxidative stress in the absence of endogenous $\mathrm{Ca}^{2+}$, following 15 min of incubation, as suggested in our previous study (1). The observed oxidation of glutathione and pyridine nucleotides demonstrate 

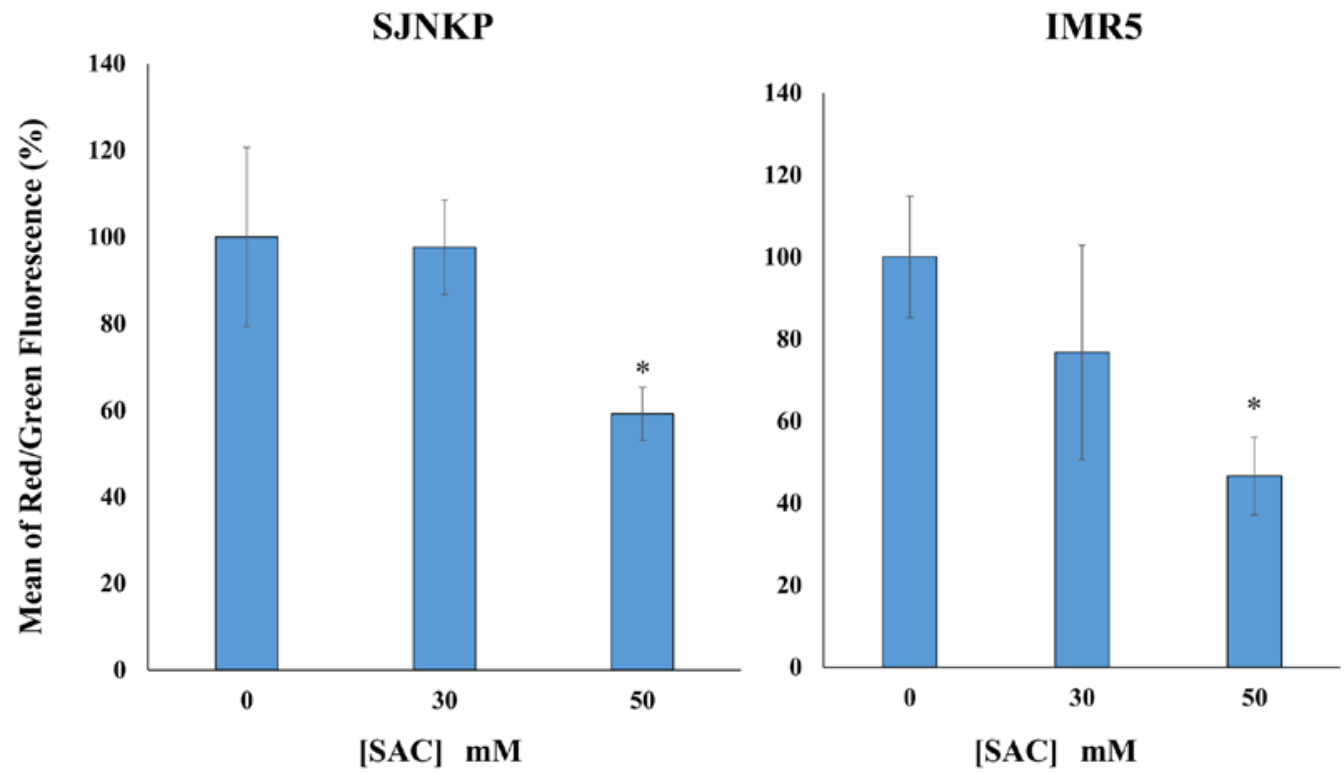

Figure 9. Effects of the treatment with SAC on mitochondrial membrane potential on SJ-N-KP and IMR5 cells. The neuroblastoma cells, SJ-N-KP and IMR5, were incubated with increasing concentrations $(0,30$ and $50 \mathrm{mM})$ of SAC for $48 \mathrm{~h}$ at $37^{\circ} \mathrm{C}$. Subsequently, mitochondrial membrane depolarization was assayed using JC-1 and was examined by flow cytometry. The ratio of red (JC-1 aggregate)/green (JC-1 monomer) fluorescence intensity was used to represent the mitochondrial membrane potential. Results represent the mean values \pm SD from 3 independent experiments. Data were analyzed by one-way ANOVA, followed by Dunnett's post hoc test. ${ }^{*} \mathrm{P}<0.05$ vs. control SJ-N-KP or IMR5 cells. SAC, S-allyl-L-cysteine.

the involvement of a coupled redox cycling between the above compounds that is essential for mitochondrial physiology.

To support the anti-proliferative effects of AGE, experiments were performed on NB cancer cells, the most common cancer observed in infancy and the most frequent cause of death from extracranial malignant solid tumors in children (42). NB originates from the sympathoadrenal lineage of neural crest and accounts for $15 \%$ of childhood cancer mortality. The amplification of the oncogene, N-Myc, is a well-established poor prognostic marker for NB. The N-Myc amplification status is strongly associated with a higher tumor aggression and resistance to treatment. Therefore, besides the current treatments that include chemotherapy, surgery and radiation, new therapies for patients with N-Myc-amplified NB need to be developed $(43,44)$. In this study, two NB cell lines, SJ-N-KP and MYCN-amplified IMR5, were treated with an AGE constituent, SAC, with the aim to demonstrate the anticancer activity of this compound and to elucidate the possible underlying molecular mechanisms (Figs. 4 and 5, GC-MS chromatograms). During the aging of garlic (up to 20 months), the hydrolysis of the $\gamma$-glutamyl- $S$-allylcysteine by $\gamma$-glutamyltransferase to form SAC, the major organosulfur compound of AGE occurs (45). SAC, an antioxidant with neuroprotective properties, is a water-soluble and non-toxic compound (46), and is stable since it remains relatively unaltered in AGE for up to 2 years (45). The antioxidant properties of SAC have been attributed to its capacity to (reviewed in ref. 47) i) scavenge ROS/RNS due to the allyl group in its structure (48), thus protecting cells against lipid peroxidation, protein oxidation and nitration as well as mitochondrial damage; ii) chelate metal ions implicated in ROS/RNS formation, such as $\mathrm{Fe}^{2+}$ and $\mathrm{Cu}^{2+}(49)$; iii) increase non-enzymatic antioxidant defense, such as reduced glutathione (50); iv) inhibit pro-oxidant enzymes, such as NADPH oxidase and nitric oxide synthase (51); v) inhibit the NF- $\mathrm{B}$ inflammatory pathway $(52,53)$; and vi) contribute to anti-inflammatory responses by increasing NO in endothelial cells (51).

In this study, the effects of cell growth inhibition induced by SAC on NB cells were investigated. Since the efficacy of therapeutic agents depends on its long-term effect on cancer cells, we examined the effects of the treatments on in vitro tumorigenic capacity by employing MTT assay, which is widely considered to be a valid method for the evaluation of tumor cell sensitivity to anticancer drugs. Following treatment of the NB cells, SJ-N-KP and MYCN-amplified IMR5 cells, with SAC at $20 \mathrm{mM}$ at $37^{\circ} \mathrm{C}$ for $48 \mathrm{~h}$, cell proliferation was detected by MTT assay. The cell survival assay revealed that SAC exerted an anti-proliferative effect on both NB human cancer cells (Fig. 6).

Apoptosis was evaluated by flow cytometry, in the same experimental condition, using Annexin V-FITC labeling and DNA staining with propidium iodide. The results revealed that treatment with SAC increased the percentage of apoptotic cells in a SAC dose-dependent manner. The percentages of Annexin V-positive cells were $48.0 \%$ in the SJ-N-KP and $50.1 \%$ in the IMR 5 cells (Fig. 7), indicating that treatment with $\mathrm{SAC}$ was able to induce cell death through apoptosis. Cell cycle analysis revealed that the percentages of Annexin V-positive cells were in accordance with those of cells showing a hypodiploid sub-G1 peak (Fig. 8). It is known that the mitochondria play a pivotal role in the intrinsic apoptotic pathway and a reduction in $\Delta \psi \mathrm{m}$ is an early irreversible step (54). By labeling the NB cells with the probe JC-1 dye, cytofluorimetric analysis revealed that the target of SAC was the mitochondria. SAC-induced apoptosis was preceded by the $\Delta \psi \mathrm{m}$ dissipation in both the IMR5 and SJ-N-KP cells, following treatment with 30 and $50 \mathrm{mM} \mathrm{SAC} \mathrm{(Fig.} \mathrm{9).} \mathrm{In} \mathrm{view} \mathrm{of} \mathrm{these} \mathrm{results,} \mathrm{the} \mathrm{use}$ of AGE and SAC in cancer therapy deserves to be taken into consideration. The findings indicate that both AGE and SAC 
induce the apoptosis of cancer cells by altering mitochondrial permeability transition and that the mitochondria may become a promising target for the treatment of malignancies.

\section{Acknowledgements}

The authors would like to thank the 'International Polyamine Foundation-ONLUS' for the availability to look up the polyamine documentation. AGE and SAC were a kind gift from Wakunaga Pharmaceutical Co. Ltd. (Japan).

\section{Funding}

This study was funded by the generous support of 'La Sapienza' University of Rome and Italian MIUR (Ministero dell'Istruzione, dell'Università e della Ricerca), AIRC IG 17575, IG 20801; Istituto Pasteur-Fondazione Cenci-Bolognetti, AFM-Telethon grant \#21025. EA would like to thank Wakunaga Pharmaceutical Co. Ltd. (Japan) for the scholarship given to $\mathrm{YK}$ for the support of his PhD research work.

\section{Availability of data and materials}

All data generated or analyzed during this study are included in this published article or are available from the corresponding author on reasonable request.

\section{Authors' contributions}

EA, YK and AT conceived this study and coordinated the collaboration among the authors. YK, LDV, AM and GC performed all the experiments on the NB cancer cells. EA, AT, AM and AG optimized the protocols for the analyses performed by flow cytometry and GC-MS. All authors wrote the manuscript and all authors have read and approved the final manuscript.

\section{Ethics approval and consent to participate}

The animal experimental procedures were approved by the local Ethics Committee for Animal Experimentation (CEASA) (protocol no. 3619, 15.1.2014) and performed in agreement with the international guidelines as well as European Communities Council Directive and National Regulations (CEE Council 86/609 and DL 116/92).

\section{Patient consent for publication}

Not applicable.

\section{Competing interests}

The authors declare that they have no competing interests.

\section{References}

1. Ohkubo S, Dalla Via L, Grancara S, Kanamori Y, GarcíaArgáez AN, Canettieri G, Arcari P, Toninello A and Agostinelli E: The antioxidant, aged garlic extract, exerts cytotoxic effects on wild-type and multidrug-resistant human cancer cells by altering mitochondrial permeability. Int J Oncol 53: 1257-1268, 2018.
2. Fleischauer AT, Poole C and Arab L: Garlic consumption and cancer prevention: Meta-analyses of colorectal and stomach cancers. Am J Clin Nutr 72: 1047-1052, 2000.

3. Rahman K and Lowe GM: Garlic and cardiovascular disease: A critical review. J Nutr 136 (Suppl 3): 736S-740S, 2006.

4. Banerjee SK and Maulik SK: Effect of garlic on cardiovascular disorders: A review. Nutr J 1: 4, 2002.

5. Sundaresan $S$ and Subramanian P: Prevention of $\mathrm{N}$-nitrosodiethylamine-induced hepatocarcinogenesis by S-allylcysteine. Mol Cell Biochem 310: 209-214, 2008.

6. Thomson M and Ali M: Garlic [Allium sativum]: A review of its potential use as an anti-cancer agent. Curr Cancer Drug Targets 3: 67-81, 2003.

7. Ray B, Chauhan NB and Lahiri DK: Oxidative insults to neurons and synapse are prevented by aged garlic extract and S-allyl-L-cysteine treatment in the neuronal culture and APP-Tg mouse model. J Neurochem 117: 388-402, 2011.

8. Amagase H, Petesch BL, Matsuura H, Kasuga S and Itakura Y: Intake of garlic and its bioactive components. J Nutr 131: 955S-962S, 2001.

9. Cemil B, Gokce EC, Kahveci R, Gokce A, Aksoy N, Sargon MF, Erdogan B and Kosem B: Aged garlic extract attenuates neuronal injury in a rat model of spinal cord ischemia/reperfusion injury. J Med Food 19: 601-606, 2016.

10. Hu X, Cao BN, Hu G, He J, Yang DQ and Wan YS: Attenuation of cell migration and induction of cell death by aged garlic extract in rat sarcoma cells. Int J Mol Med 9: 641-643, 2002.

11. Fallah-Rostami F, Tabari MA, Esfandiari B, Aghajanzadeh $\mathrm{H}$ and Behzadi MY: Immunomodulatory activity of aged garlic extract against implanted fibrosarcoma tumor in mice. $\mathrm{N}$ Am J Med Sci 5: 207-212, 2013

12. Li G, Qiao C, Lin R, Pinto J, Osborne M and Tiwari R: Antiproliferative effects of garlic constituents in cultured human breast-cancer cells. Oncol Rep 2: 787-791, 1995.

13. Shirin H, Pinto JT, Kawabata Y, Soh JW, Delohery T, Moss SF, Murty V, Rivlin RS, Holt PR and Weinstein IB: Antiproliferative effects of S-allylmercaptocysteine on colon cancer cells when tested alone or in combination with sulindac sulfide. Cancer Res 61: 725-731, 2001

14. Hosono T, Fukao T, Ogihara J, Ito Y, Shiba H, Seki T and Ariga T: Diallyl trisulfide suppresses the proliferation and induces apoptosis of human colon cancer cells through oxidative modification of beta-tubulin. J Biol Chem 280: 41487-41493, 2005.

15. Howard EW, Ling MT, Chua CW, Cheung HW, Wang X and Wong YC: Garlic-derived S-allylmercaptocysteine is a novel in vivo antimetastatic agent for androgen-independent prostate cancer. Clin Cancer Res 13: 1847-1856, 2007.

16. Sriram N, Kalayarasan S, Ashokkumar P, Sureshkumar A and Sudhandiran G: Diallyl sulfide induces apoptosis in Colo 320 DM human colon cancer cells: Involvement of caspase-3, NF-kappaB, and ERK-2. Mol Cell Biochem 311: 157-165, 2008

17. Lai KC, Kuo CL, Ho HC, Yang JS, Ma CY, Lu HF, Huang HY, Chueh FS, Yu CC and Chung JG: Diallyl sulfide, diallyl disulfide and diallyl trisulfide affect drug resistant gene expression in colo 205 human colon cancer cells in vitro and in vivo. Phytomedicine 19: 625-630, 2012.

18. Yan JY, Tian FM, Hu WN, Zhang JH, Cai HF and Li N: Apoptosis of human gastric cancer cells line SGC 7901 induced by garlicderived compound S-allylmercaptocysteine (SAMC). Eur Rev Med Pharmacol Sci 17: 745-751, 2013.

19. Zhang H, Wang K, Lin G and Zhao Z: Antitumor mechanisms of S-allyl mercaptocysteine for breast cancer therapy. BMC Complement Altern Med 14: 270, 2014.

20. Ng KT, Guo DY, Cheng Q, Geng W, Ling CC, Li CX, Liu XB, Ma YY, Lo CM, Poon RT, et al: A garlic derivative, S-allylcysteine (SAC), suppresses proliferation and metastasis of hepatocellular carcinoma. PLoS One 7: e31655, 2012.

21. Liu Z, Li M, Chen K, Yang J, Chen R, Wang T, Liu J, Yang W and Ye Z: S-allylcysteine induces cell cycle arrest and apoptosis in androgen-independent human prostate cancer cells. Mol Med Rep 5: 439-443, 2012.

22. Chung LY: The antioxidant properties of garlic compounds: Allyl cysteine, alliin, allicin, and allyl disulfide. J Med Food 9: 205-213, 2006

23. García E, Santana-Martínez R, Silva-Islas CA, ColínGonzález AL, Galván-Arzate S, Heras Y, Maldonado PD, Sotelo J and Santamaría A: S-allyl cysteine protects against MPTP-induced striatal and nigral oxidative neurotoxicity in mice: Participation of Nrf2. Free Radic Res 48: 159-167, 2014. 
24. Xu YS, Feng JG, Zhang D, Zhang B, Luo M, Su D and Lin NM: S-allylcysteine, a garlic derivative, suppresses proliferation and induces apoptosis in human ovarian cancer cells in vitro. Acta Pharmacol Sin 35: 267-274, 2014.

25. Compston A and Coles A: Multiple sclerosis. Lancet 372: $1502-1517,2008$

26. Lassmann H: Pathophysiology of inflammation and tissue injury in multiple sclerosis: What are the targets for therapy. J Neuro Sci 306: 167-169, 2011.

27. Zeinali H, Baluchnejadmojarad T, Fallah S, Sedighi M Moradi N and Roghani M: S-allyl cysteine improves clinical and neuropathological features of experimental autoimmune encephalomyelitis in C57BL/6 mice. Biomed Pharmacother 97: $557-563,2018$

28. Kyo E, Uda N, Kasuga S and Itakura Y: Immunomodulatory effects of aged garlic extract. J Nutr 131: 1075S-1079S, 2001.

29. Morihara N, Sumioka I, Moriguchi T, Uda N and Kyo E: Aged garlic extract enhances production of nitric oxide. Life Sci 71: 509-517, 2002.

30. Imai J, Ide N, Nagae S, Moriguchi T, Matsuura $H$ and Itakura Y: Antioxidant and radical scavenging effects of aged garlic extract and its constituents. Planta Med 60: 417-420, 1994.

31. Timeus F, Crescenzio N, Doria A, Foglia L, Pagliano S, Ricotti E, Fagioli F, Tovo PA and Cordero di Montezemolo L: In vitro anti-neuroblastoma activity of saquinavir and its association with imatinib. Oncol Rep 27: 734-740, 2012.

32. van Engeland M, Nieland LJ, Ramaekers FC, Schutte B and Reutelingsperger CP: Annexin V-affinity assay: A review on an apoptosis detection system based on phosphatidylserine exposure. Cytometry 31: 1-9, 1998.

33. Nicoletti I, Migliorati G, Pagliacci MC, Grignani F and Riccardi C: A rapid and simple method for measuring thymocyte apoptosis by propidium iodide staining and flow cytometry. J Immunol Methods 139: 271-279, 1991.

34. Jiménez-Martín E, Ruiz J, Pérez-Palacios T, Silva A and Antequera T: Gas chromatography-mass spectrometry method for the determination of free amino acids as their dimethyl-tert-butylsilyl (TBDMS) derivatives in animal source food. J Agric Food Chem 60: 2456-2463, 2012

35. Frezza C, Cipolat S and Scorrano L: Organelle isolation: Functional mitochondria from mouse liver, muscle and cultured fibroblasts. Nat Protoc 2: 287-295, 2007.

36. Gornall AG, Bardawill CJ and David MM: Determination of serum proteins by means of the biuret reaction. J Biol Chem 177: 751-766, 1949.

37. Kamo N, Muratsugu M, Hongoh R and Kobatake Y: Membrane potential of mitochondria measured with an electrode sensitive to tetraphenyl phosphonium and relationship between proton electrochemical potential and phosphorylation potential in steady state. J Membr Biol 49: 105-121, 1979.

38. Rottenberg H: Non-equilibrium thermodynamics of energy conversion in bioenergetics. Biochim Biophys Acta 549: 225-253, 1979.

39. Tietze F: Enzymic method for quantitative determination of nanogram amounts of total and oxidized glutathione: Applications to mammalian blood and other tissues. Anal Biochem 27: 502-522, 1969.

40. Kanda Y: Investigation of the freely available easy-to-use software 'EZR' for medical statistics. Bone Marrow Transplant 48: 452-458, 2013.

41. Ho JN, Kang M, Lee S, Oh JJ, Hong SK, Lee SE and Byun SS: Anticancer effect of S-allyl-L-cysteine via induction of apoptosis in human bladder cancer cells. Oncol Lett 15: 623-629, 2018.
42. Hoehner JC, Gestblom C, Hedborg F, Sandstedt B, Olsen L and Påhlman S: A developmental model of neuroblastoma: Differentiating stromapoor tumors' progress along an extra-adrenal chromaffin lineage. Lab Invest 75: 659-675, 1996.

43. Huang $M$ and Weiss WA: Neuroblastoma and MYCN. Cold Spring Harb Perspect Med 3: a014415, 2013.

44. Fonseka P, Liem M, Ozcitti C, Adda CG, Ang CS and Mathivanan S: Exosomes from N-Myc amplified neuroblastoma cells induce migration and confer chemoresistance to non-N-Myc amplified cells: Implications of intratumour heterogeneity. J Extracell Vesicles 8: 1597614, 2019.

45. Lawson LD: Garlic: A review of its medicinal effects and indicated active compounds. In: Phytomedicines of Europe: Chemistry and biological activity. Lawson LD and Bauer R (eds). ACS symposium series, Vol. 691. American Chemical Society, Washington, DC, USA, pp 176-209, 1998.

46. Kodera Y, Suzuki A, Imada O, Kasuga S, Sumioka I, Kanezawa A, Taru N, Fujikawa M, Nagae S, Masamoto K, et al: Physical, chemical, and biological properties of S-allylcysteine, an amino acid derived from garlic. J Agric Food Chem 50: 622-632, 2002

47. Colín-González AL, Santana RA, Silva-Islas CA, ChánezCárdenas ME, Santamaría A and Maldonado PD: The antioxidant mechanisms underlying the aged garlic extract- and S-allylcysteine-induced protection. Oxid Med Cell Longev 2012: 907162, 2012.

48. Maldonado PD, Alvarez-Idaboy JR, Aguilar-González A, Lira-Rocha A, Jung-Cook H, Medina-Campos OM, Pedraza-Chaverri J and Galano A: Role of allyl group in the hydroxyl and peroxylradical scavenging activity of S-allylcysteine. J Phys Chem B 115: 13408-13417, 2011.

49. Dairam A, Fogel R, Daya S and Limson JL: Antioxidant and iron-binding properties of curcumin, capsaicin, and $\mathrm{S}$-allylcysteine reduce oxidative stress in rat brain homogenate. J Agric Food Chem 56: 3350-3356, 2008.

50. Pinto JT, Qiao C, Xing J, Rivlin RS, Protomastro ML, Weisler ML, Tao Y, Thaler H and Heston WD: Effects of garlic thioallyl derivatives on growth, glutathione concentration, and polyamine formation of human prostate carcinoma cells in culture. Am J Clin Nutr 66: 398-405, 1997.

51. Kim KM, Chun SB, Koo MS, Choi WJ, Kim TW, Kwon YG, Chung HT, Billiar TR and Kim YM: Differential regulation of NO availability from macrophages and endothelial cells by the garlic component S-allyl cysteine. Free Radic Biol Med 30: 747-756, 2001.

52. Kim SR, Jung YR, An HJ, Kim DH, Jang EJ, Choi YJ, Moon KM, Park MH, Park CH, Chung KW, et al: Anti-wrinkle and anti-inflammatory effects of active garlic components and the inhibition of MMPs via NF- $\kappa \mathrm{B}$ signaling. PLoS One 8: e73877, 2013

53. Mong MC and Yin MC: Nuclear factor $\kappa \mathrm{B}$-dependent anti-inflammatory effects of S-allyl cysteine and S-propyl cysteine in kidney of diabetic mice. J Agric Food Chem 60: 3158-3165, 2012.

54. Grancara S, Zonta F, Ohkubo S, Brunati AM, Agostinelli E and Toninello A: Pathophysiological implications of mitochondrial oxidative stress mediated by mitochondriotropic agents and polyamines: The role of tyrosine phosphorylation. Amino Acids 47: $869-883,2015$

This work is licensed under a Creative Commons Attribution-NonCommercial-NoDerivatives 4.0 International (CC BY-NC-ND 4.0) License. 